\title{
TO SETTLE OR EMPANEL? AN EMPIRICAL ANALYSIS OF LITIGATION AND SETTLEMENT AT THE WORLD TRADE ORGANIZATION
}

\author{
ANDREW GUZMAN and BETH A. SIMMONS*
}

\begin{abstract}
This paper seeks to understand the factors that cause disputes at the World Trade Organization to move from the negotiation stage to the panel stage. We hypothesize that transfer payments between states are costly to arrange and that the lowest-cost transfers are those that relate directly to the issue in dispute. This implies that when the subject matter of the dispute has an all-or-nothing character and leaves little room for compromise (for example, health and safety regulations), the parties' ability to reach an agreement through the use of transfers is restricted. In contrast, if the subject matter of dispute permits greater flexibility (for example, tariff rates), the parties can more easily structure appropriate transfer payments through adjustments to the disputed variable. We conduct an empirical test of this hypothesis, finding support for it among democratic states.
\end{abstract}

\section{INTRODUCTION}

T HE World Trade Organization (WTO) came into being on January 1, 1995, to replace the General Agreement on Tariffs and Trade (GATT). Of the changes to international trade brought about through the establishment of the WTO, one of the most important-and almost certainly the most discussed-is the dispute resolution procedure. The new procedure was developed in an attempt to improve on what existed under GATT, most notably by shortening the duration of cases and eliminating the veto power states previously had over the adoption of panel rulings. Now that the dispute settlement procedure has passed its seventh birthday, enough cases have been handled to permit empirical studies of that procedure.

\footnotetext{
* Guzman is at Boalt Hall School of Law, University of California, Berkeley; Simmons is at Department of Political Science, University of California, Berkeley. Based on a paper presented at the conference Rational Choice and International Law, University of Chicago Law School, April 27-28, 2001. Thanks to Robert Cooter for valuable discussion of the ideas contained in this paper. We would like to acknowledge the extremely helpful research assistance of Jennie Wang, Jenny Chang, Howard Cheung, and Julieta Lerner, who assisted through the Undergraduate Research Apprentice Program at the University of California, and Ryan Waterman, University of Califomia Law School. Andrew Guzman thanks the John M. Olin Foundation for financial assistance. All errors remain our own.
} 
This paper examines the use of the WTO's dispute settlement mechanism by states. In particular, we are interested in understanding what causes disputes to move from the negotiation stage to the panel stage. Standard models of dispute settlement within a domestic context usually focus on how informational asymmetries affect the probability of settlement. ${ }^{1}$ Although informational issues may be relevant at the WTO as well, we test an alternative, though not necessarily mutually exclusive, hypothesis. When states negotiate over a dispute at the WTO, their negotiations are typically focused on the specific source of the dispute. This inevitably constrains their ability to reach an agreement because transfer payments between the parties are more difficult than they would be if the parties were prepared to make transfers in the form of, for example, cash. Furthermore, to the extent that the only transfers considered are those that can be made by manipulating the disputed policy variables, certain disputes will be particularly difficult to settle prior to the panel stage. When the subject matter of the dispute has an all-or-nothing character and leaves little room to compromise (which we will refer to as a discontinuous variable), as might be true of health and safety regulations, for example, the parties' ability to reach an agreement through the use of transfers is restricted. Settlement through negotiation may be even more difficult when governments cannot easily fashion side payments to compensate for a major indivisible concession. In contrast, if the subject matter of the dispute permits greater flexibility (a continuous variable), such as the setting of a tariff level, the parties can more easily structure appropriate transfer payments by adjusting that variable.

The paper proceeds as follows. Section II provides a sketch of the WTO dispute settlement procedure. Section III presents a simple model of settlement negotiation in the presence of transaction costs to demonstrate that parties are more likely to proceed to a panel if transaction costs are higher. Section IV presents the data we use in our empirical tests, and Section V discusses the results.

\section{Dispute Settlement at the World Trade Organization}

The dispute settlement procedures of the WTO are laid out in the Dispute Settlement Understanding. ${ }^{2}$ There is a voluminous literature that describes and evaluates the dispute settlement at the WTO. In the interests of brevity, this section limits the discussion of the dispute settlement procedures to that

\footnotetext{
' See Lucian Ayre Bebchuk, Litigation and Settlement under Imperfect Information, 15 Rand J. Econ. 404 (1984); George L. Priest \& Benjamin Klein, The Selection of Disputes for Litigation, 13 J. Legal Stud. 1 (1984); John P. Gould, The Economics of Legal Conflicts, 2 J. Legal Stud. 279 (1973).

${ }^{2}$ Understanding on Rules and Procedures Governing the Settlement of Disputes, Legal Instruments vol. 31, 33 I.L.M. 112 (1994) (hereinafter DSU).
} 
which is necessary to understand the theoretical and empirical analysis that follows.

The dispute resolution process includes several phases: consultation, panel investigation and report, appellate review, decision adoption, and implementation. When a dispute arises between WTO member states, either party may call for consultation. ${ }^{3}$ Members are required to enter into consultation within 30 days of such a request; if a member refuses to do so, the complaining party may ask for the establishment of a panel. ${ }^{4}$ If consultation fails to yield a settlement 60 days after the request is made, the complaining party may request the establishment of a panel, ${ }^{5}$ which must be established no later than at the meeting of the Dispute Settlement Body (DSB) that follows the request. ${ }^{6}$ Panels typically consist of three people from countries not party to the dispute. ${ }^{7}$ If the parties fail to agree on the composition of the panel within 20 days of its establishment, the director-general is authorized to decide the issue upon the request of either party. ${ }^{8}$

Once issued, panel reports are considered for adoption by the DSB. Unless the DSB decides by consensus not to adopt the report or one of the parties notifies the DSB of its intention to appeal, it is automatically adopted within 60 days of issuance. ${ }^{9}$ If one or both parties request an appeal, a three-person appellate panel is established. Appeals are intended to be limited to issues of law covered in the panel report and legal interpretations developed by the panel. The entire process, from establishment of a panel to the adoption of the panel or appellate body report by the DSB, is to take place within 9 months if there is no appeal and 12 months if there is an appeal. ${ }^{10}$

If the offending party fails to implement a panel recommendation or ruling within a reasonable period of time, it must enter into negotiations with the aggrieved party to develop a satisfactory scheme of compensation. "If there is no agreement on compensation within 20 days, a party to the dispute may request authorization of the DSB to suspend concessions or other obligations to the other party. ${ }^{12}$ The DSB will grant such a request within 30 days of

\footnotetext{
${ }^{3}$ Parties are also free to request "good offices, conciliation, and mediation" at any time. DSU, art. 5(3).

${ }^{4} I d$. at art. 4(3). Notice that the consensus requirement allows the complaining party to force the establishment of a panel.

${ }^{5}$ Id. at art. $4(7)$

${ }^{6}$ Id. at art. $6(1)$

${ }^{7} I d$. at art. 8(3). The parties can choose to have five panelists, but they must do so within 10 days of the establishment of the panel.

${ }^{8}$ Id. at art. 8(7).

${ }^{9} I d$. at art. $16(4)$. Recall that both parties to the dispute are members of the DSB, making a consensus against adoption unlikely.

${ }^{10} I d$. at art. 20.

"Id. at art. 22.

${ }^{12}$ Id. at art. 22(2).
} 
the expiry of the agreed time frame for implementation unless it decides by consensus not to do so. The party subject to retaliation may object, in which case the issue goes to arbitration.

In summary, then, the full dispute settlement provisions of the WTO provide for the filing of a grievance by the complainant, a period of consultation, a panel investigation and report, an appellate panel and report, implementation, negotiation regarding compensation, and retaliation. The parties are able to settle the case through mutual consent at any point in the process. For the purposes of this paper, it is settlement prior to the panel stage that is of interest. This is the stage most analogous to the question of settlement before "trial" in the existing litigation and settlement literature. In any event, virtually all cases for which a panel decision is announced are appealed, making the prepanel stage the one time, prior to final adjudication, at which the parties truly enter into negotiations.

\section{A Model of World Trade Organization Negotiation and SetTlement}

There is a substantial law and economics literature on litigation and settlement in the domestic context. ${ }^{13}$ One of the central claims of that literature is that in the absence of transaction costs and with symmetric information, all cases will settle. This represents a simple application of the Coase theorem-as long as there are gains from settlement, the parties will reach an agreement to maximize their joint gains.

In the context of litigation at the WTO, the gains from settlement come from at least two sources. First, the litigation itself imposes costs on the parties. Most obviously, the parties must pay their lawyers to prepare and argue the case and must pay their diplomats to prevent the dispute from harming relations with one another. Although states may not pay their lawyers (and do not pay their diplomats) more for bringing a case than they would in the absence of the case, there remains an opportunity cost associated with devoting those resources to the litigation. A second, less obvious cost is the political cost of the case. An ongoing dispute may harm the relations between the states, which represents a loss in the form of reduced future benefits. Furthermore, some cases will represent a threat to the political standing of national leaders. ${ }^{14}$

Failure to settle is normally attributed to some combination of informational asymmetries and transaction costs. Optimism on the part of the parties is one of the most commonly cited explanations for litigation. The settlement range with full information lies between the expected payoffs of the two

\footnotetext{
${ }^{13}$ See note 1 supra.

${ }^{14}$ On the other hand, pursuing a case may generate political gains to the leaders of a state that outweigh any benefit from settlement.
} 
parties in the event of a trial. Thus, for example, if the parties expect the court to award damages of $\$ 1,000$ and the costs of trial are expected to be $\$ 200$ for each party, then the plaintiff (P) will refuse to settle for less than $\$ 800$, and the defendant (D) will refuse to pay more than $\$ 1,200$. The settlement range, therefore, is $\$ 800-\$ 1,200$. If the parties are optimistic, however, the settlement range may shrink or disappear altogether. Suppose that $\mathrm{P}$ expects to be awarded $\$ 1,300$ and the defendant expects the award to be only $\$ 700$. In that case, $P$ will refuse to accept any amount less than $\$ 1,100$, and $D$ will refuse to pay more than $\$ 900$. The bargaining space is eliminated in this example, making settlement impossible. If instead $\mathrm{P}$ expected to win $\$ 1,200$ and $\mathrm{D}$ expected to have to pay $\$ 800$, the bargaining space is reduced to a single point, $\$ 1,000$, where we would normally expect settlement to take place.

In the context of the WTO, this optimism model could prevent settlement in the same way as it does in the domestic context. If the plaintiff expects a favorable ruling from the panel, it will refuse to settle unless it receives concessions that are at least as valuable as the gains from that panel ruling minus the litigation costs. In a typical case, for example, the plaintiff may be seeking a ruling that a particular practice is a violation and that the defendant must stop. The plaintiff will pursue the case to a panel unless it is offered a settlement whose value exceeds such a ruling (discounted to reflect the risk that the plaintiff will lose) minus the costs of litigation before a panel. On the other hand, the defendant will not offer concessions greater than what it expects to lose before a panel plus litigation costs.

Although informational asymmetries may prevent settlement, this paper is primarily interested in an alternative explanation for the failure to settle. One can think of informational issues as the architects of the settlement range-determining if it is small, large, or nonexistent. Transaction costs, on the other hand, determine whether the parties can reach a settlement within the range. The specific form of cost that we have in mind is hypothesized to frustrate the attempts of states to make the transfers required to reach a settlement. To illustrate the problem, consider another domestic analogy. If the settlement range facing the parties is from $\$ 120$ to $\$ 150$, but they have only $\$ 100$ bills and cannot make change, they will not be able to settle. ${ }^{15}$ This example conveys the intuition behind the hypothesis. Although it is a problem that is unlikely to affect negotiations in many domestic contexts, we hypothesize that it may be relevant at the WTO.

We hypothesize that states entering into negotiations regarding a dispute are likely to focus the negotiations on the subject matter of that dispute. They are less likely to enter into wide-ranging negotiations that cover other aspects of their trade relationship. This constraint on negotiation, to the extent it exists, is not the product of WTO rules. In fact, the WTO encourages set-

\footnotetext{
${ }^{15}$ We owe thanks to Alan Sykes for this colorful analogy.
} 
tlement and in no way discourages the inclusion in negotiations of issues unrelated to the dispute. ${ }^{16}$ Rather, the constraint might come from the political realities facing the states involved and the legal obligation of the mostfavored-nation requirement. Consider the perspective of national negotiators as they try to settle a dispute. If the parties are able to reach an agreement without going beyond the subject of the dispute, negotiators face no significant domestic hurdles in order to get the negotiated agreement implemented. As the concessions wander farther from the dispute, however, the negotiators are less likely to have the authority and the ability to make concessions on behaif of their state. Imagine, for example, that in negotiations between the United States and Europe, the parties would like to provide for streamlined regulatory approval of U.S. pharmaceuticals by Europe in exchange for a settlement of a U.S. complaint regarding unrelated issues. To make such a promise, European negotiators must consult with, and get the support of, the relevant regulatory bodies. Without adequate political support for a concession of this sort, of course, the European promise is not credible. One can, of course, imagine a situation in which the parties reach an agreement involving transfers in unrelated areas. It is enough for the present inquiry if such transfers are more difficult or more costly than concessions closely related to the dispute.

A second reason to think that transfers cannot be arranged costlessly is the most-favored-nation obligation. In a trade dispute within the WTO, the most obvious form of concession is another trade issue. Thus, for example, if, in order to settle a dispute over health and safety measures, a state makes concessions regarding market access in agriculture, those concessions may have to be granted to every WTO member state. This obviously hampers efforts to find suitable transfers.

Finally, it appears that the most obvious mechanism for compensatory transfers-the payment of cash-is not commonly used. For reasons that are beyond the scope of this paper, states appear to be reluctant to enter into cash transactions to settle disputes.

Skeptics may insist that the absence of a formal constraint on the subject matter of negotiations implies that the parties can, at virtually zero cost, make the transfers to one another that are necessary to achieve settlement. As a matter of theory, it is true that we are unable to prove that states face significant transaction costs when they try to increase the scope of negotiations. It is for precisely this reason that we conduct an empirical examination of the hypothesis.

If states are, in fact, constrained in their willingness or ability to negotiate

\footnotetext{
${ }^{16} \mathrm{~A}$ related point, which we do not explore here, is that the severity of distribution problems could actually account for the changing scope of WTO trade agreements. See, for example, Barbara Koremenos, Charles Lipson, \& Duncan Snidal, The Rational Design of International Institutions, 55 Int'l Org. 761, 786 (2001).
} 
over issues beyond the subject matter of a particular dispute, the ability to reach a settlement would be impaired. Specifically, one would expect settlement to be easier in disputes that implicate policies that are relatively continuous. Where the policies are relatively continuous, the parties are able to negotiate transfers in a fine-tuned way. Where they are discontinuous, however, states may face the same problem as the parties with only $\$ 100$ bills-they will be unable to find a transfer that gets them within the settlement range.

If the subject matter of the dispute features an easily adjustable policy (for example, a tariff), and there are no additional transaction costs, the parties will be able to reach a negotiated settlement rather than proceed to a panel. By adjusting the relevant policy appropriately, the parties can construct a transfer payment that makes both parties better off than they would be if they proceeded to a panel. On the other hand, if the subject matter of the dispute features a relatively discontinuous policy (for example, a ban on genetically modified foods), it may be impossible to use that policy to make the necessary transfer. As a result, the theory indicates that disputes over a relatively discontinuous policy are less likely to settle.

The balance of this paper will test the above theory with data from WTO disputes. The primary hypothesis is that disputes over issues that are relatively continuous such as tariffs, nonzero quotas, and subsidies reduce the transaction costs facing negotiators in the prepanel stage compared to the case of relatively discontinuous issues such as health and safety regulations, product classification issues, bans, ${ }^{17}$ and the absence of required laws (for example, as required under Trade-Related Aspects of Intellectual Property Rights, or TRIPS). If the above theory is correct, disputes involving discontinuous variables will proceed to a panel more frequently than disputes involving continuous variables. The remainder of the paper tests this claim.

\section{THE DATA}

To study the pattern of settlement at the WTO, we collected data on all cases filed at the WTO between its 1995 inception and the end of $2000 .^{18}$ Eleven cases were discarded because we were unable to classify them as either

\footnotetext{
${ }^{17}$ It is true that a ban can be characterized as a quota of zero and, therefore, might be classified as a continuous variable. We classify bans as discontinuous primarily because we suspect that states are more willing to change a positive quota than they are to remove an outright ban and replace it with a quota. One possible reason is that a ban represents a corner solution to the problem of establishing the desired quota level. This implies that a state with an outright ban may require significant benefits in exchange for instituting a nonzero quota. Furthermore, because a ban cannot be reduced, it is at most flexible in only one direction, which restricts its use as a form of transfer payment.

${ }^{18}$ These cases are coded on the basis of information provided by the WTO Web site, "state of play of WTO disputes" (http://www.wto.org/wto/english/tratop_e/dispu_e/dispu_e.htm, last accessed April 16, 2001).
} 
TABLE 1

Status of Cases

\begin{tabular}{lc}
\hline \hline Status & Number of Cases \\
\hline Completed & 42 \\
Inactive/settled & 51 \\
Appeal and panel reports adopted & 16 \\
Active & 13 \\
Panel report appealed & 5 \\
Panel report issued & 6 \\
Pending consultation & $\underline{83}$ \\
$\quad$ Total & 216 \\
\hline
\end{tabular}

Note. - The World Trade Organization does not offer explicit definitions of these categories. "Completed" appears to refer to a case in which the parties have completed the panel and appeals process. "Inactive/settled" appears to refer to cases in which the parties settled without the use of a panel or in which the claimant withdrew its complaint. "Appeal and panel reports adopted" refers to the subset of completed cases in which either a panel ruling has been adopted and not appealed or else an appeal has been made and the appellate ruling has been adopted. It does not imply implementation of these rulings. "Panel report appealed" refers to those cases in which the panel report has been adopted and is in the process of being appealed by one party. "Panel report issued" refers to cases in which a panel has ruled but the report has not been adopted or appealed. "Pending consultation" refers to cases currently in the consultation process (after the written request for a consultation is submitted but prior to any move to form a panel or a statement of settlement to the mutual satisfaction of the parties).

continuous or discontinuous with the available information. As of February 2001, the status of the remaining cases was as reported in Table 1.

Since we are interested in the phenomenon of dispute escalation, our analysis focuses on those cases in which a decision has been made about whether or not to convene a panel. We therefore have excluded all cases "pending consultations," with the exception of those that have been in this stage of the process for more than 3 years. In those cases, we have assumed that a panel is highly unlikely to be formed, and we therefore have coded these cases as "nonpaneled." Several of the cases in our initial sample involved multiple complainants. Since each complainant can, in principle, proceed to settle on its own, we have broken each case into dyads. ${ }^{19}$ We consider

${ }^{19}$ So, for example, WT/DS35 is a case in which Argentina, Australia, Canada, New Zealand, Thailand, and the United States all complained against Hungary's system of agricultural subsidies. We break the case down into a series of dyadic disputes (Argentina v. Hungary, Australia v. Hungary, and so on). See, for example, Marc Busch \& Eric Reinhardt, Bargaining in the Shadow of the Law: Early Settlement in GATT/WTO Disputes, 24 Fordham Int'l L. J. 158 (2000) (also available at http://www.qsilver.queensu.ca/buschm/); Marc L. Busch, Democracy, Consultation, and the Paneling of Disputes under GATT, 44 J. Conflict Resol. 425 (2000); Henrik Horn, Hakan Nordstrom, \& Petros Mavroidis, Is the Use of the WTO Dispute Settlement System Biased? (CEPR Discusion Paper No. 2340, London Centre Econ. Pol. Res. 1999); Eric Reinhardt, Adjudication without Enforcement in GATT Disputes, 45 J. Conflict Resol. 174 (2001). 
these to be independent complaints, since in principle any individual complainant could reach an agreement with the defendant through negotiation. Figures 1 and 2 display the number of instances each year in which the major economies have been involved in the subset of trade disputes we are examining.

A few points from Figure 1 are worthy of note. First, notice that the United States has been the largest single complainant every year since the WTO was founded (although there is a tie with Europe in 2000). The United States has also been the largest single defendant for 4 out of 6 years examined. Using the data in Figure 1, we calculate that the United States is either a complainant or a defendant in 51 percent of the cases, and the European Community (EC) is involved in 40 percent. Furthermore, the four countries listed are among the complainants in 63 percent of the cases and defendants in 48 percent. These figures demonstrate that the WTO dispute settlement process is used overwhelmingly, though not exclusively, for cases involving these large players. ${ }^{20}$ There do not appear to be any significant systematic changes in these patterns over the 6 years examined here.

Our main concern here is to test the theory that transaction costs-and in particular the discontinuous nature of the relevant issue-are one reason that cases escalate to panels. The theory developed above shows that transaction costs can frustrate efforts to settle a dispute. Disputes over some issues, such as tariffs, offer negotiators a relatively continuous policy variable, which makes a compromise outcome easier to achieve. Thus, for example, in a tariff dispute in which country A alleges that country B's tariff regime is a violation of its obligations under the WTO, the parties could settle the dispute by agreeing to some lower tariff rate. On the other hand, a dispute regarding, for example, a health and safety measure might represent more of an all-ornothing proposition that leaves little room for compromise.

With this transaction cost theory in mind, we coded all the WTO cases as either "continuous" or "discontinuous" based on the subject matter of the dispute. (A list of the cases and their coding is included in Appendix A.) We classified disputes over tariffs, ${ }^{21}$ nonzero quotas, ${ }^{22}$ and subsidies ${ }^{23}$ as being

${ }^{20}$ Of the 227 cases, only 8 percent involved developing countries as both defendants and complainants.

${ }^{21}$ Examples of complaints about tariffs are very common, and we coded these as continuous. For example, a complaint by the United States (WT/DS56), dated October 4, 1996, against Argentina's imposition of specific duties on footwear, textiles, apparel, and other items in excess of the bound rate is classified as continuous, as are all other complaints about tariff rates.

${ }^{22}$ Examples of quota-related disputes abound: for example, a complaint by New Zealand (WT/DS177/1), dated July 16,1999, regarding a safeguard measure imposed by the United States on imports of New Zealand lamb meat. We code this and other quotas as continuous.

${ }^{23}$ For example, the United States (WT/DS104/1) filed a complaint dated October 8, 1997, that the EC illegally subsidized the export of processed cheese. We code this and all subsidy cases as continuous. 


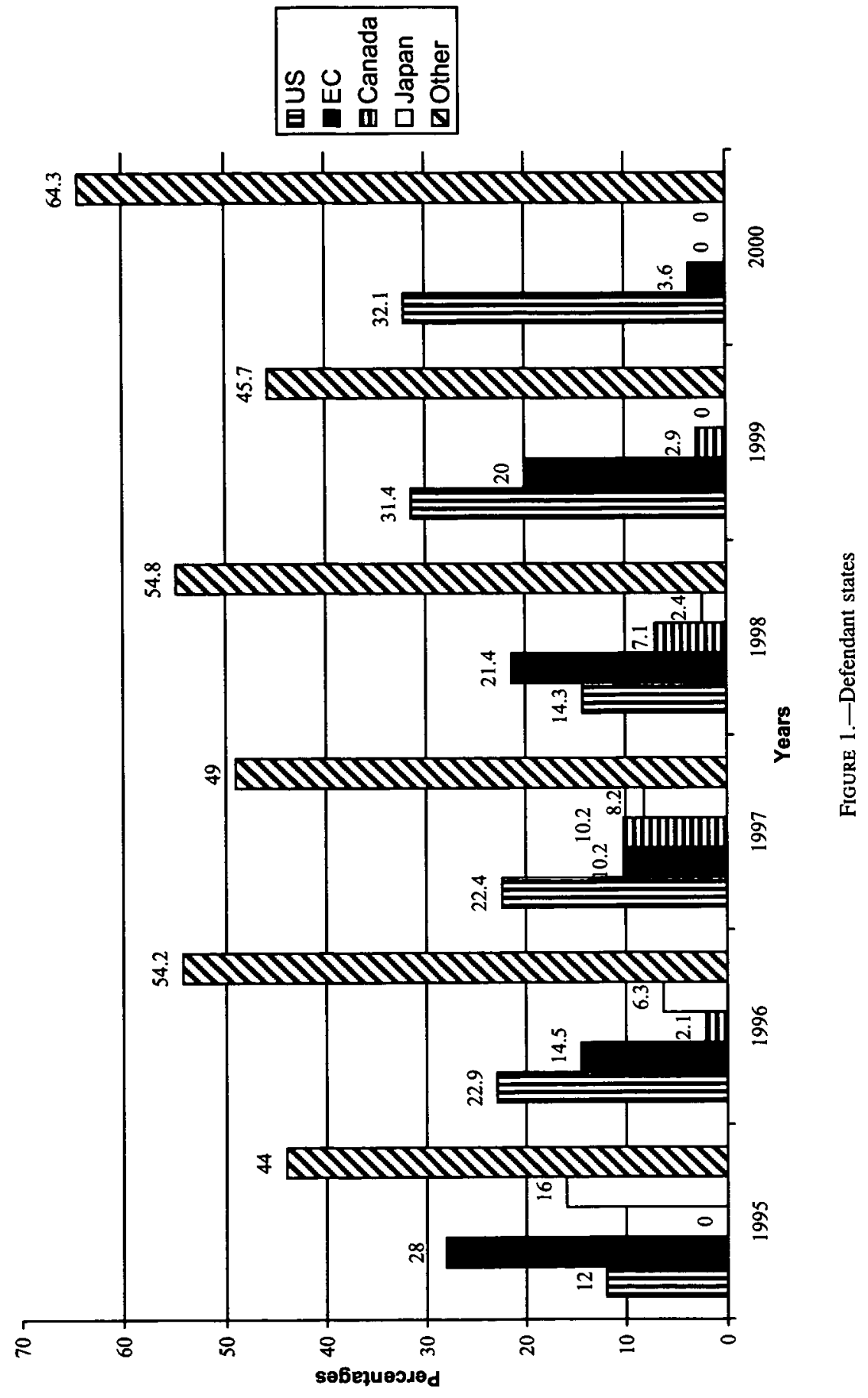

S214 


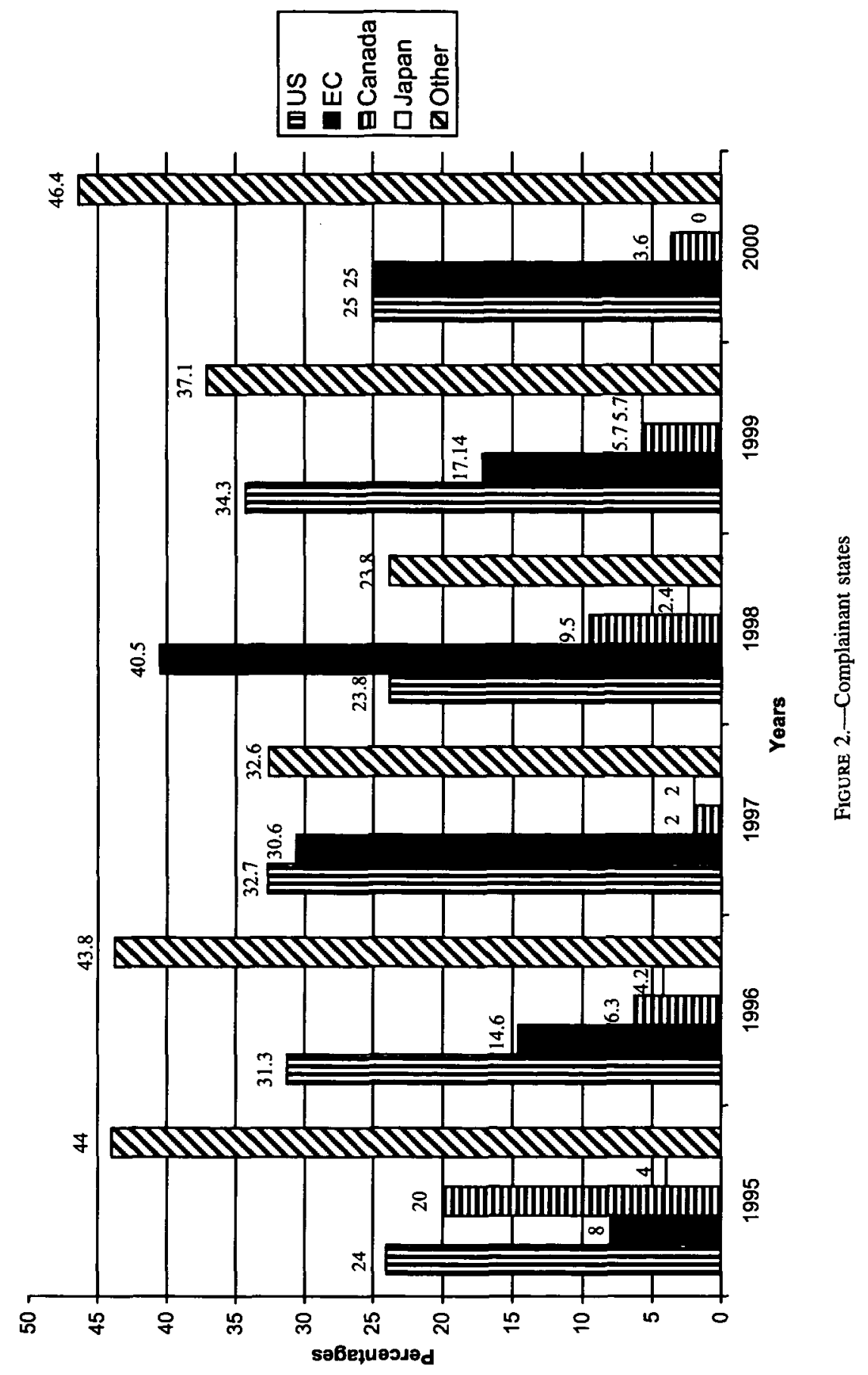


TABLE 2

Incidence of Continuous and Discontinuous Cases

\begin{tabular}{lcc}
\hline \hline & Number of Cases & Percent of Total \\
\hline Continuous & 121 & 53.30 \\
Discontinuous & 95 & 41.85 \\
Unknown & 11 & 4.85 \\
Total & 227 & 100.00 \\
\hline
\end{tabular}

relatively continuous; those involving outright bans ${ }^{24}$ health and safety regulations, ${ }^{25}$ product classification issues, ${ }^{26}$ and the absence of required laws (such as TRIPS requirements) ${ }^{27}$ were classified as relatively discontinuous. While such coding involves a judgment over which issue is the most important where multiple violations are cited, we used the judgments of three independent coders, checking in each case for intercoder reliability. The coding of cases in this fashion produced aggregate results that are presented in Table 2 (see Appendix A for a complete listing of cases, issues, and how they were coded with respect to the continuous/noncontinuous distinction).

While the continuous nature of the issue under dispute is the primary variable of interest, it is important to control for a number of other conditions that could significantly affect the bargaining process and hence the propensity to form a panel. One set of conditions that could affect the ability to settle during consultations might be the relative economic or political power of the parties to the dispute. Overwhelming power disparities might lead to

\footnotetext{
${ }^{24}$ For example, the EC filed a complaint (WT/DS100/1) against the United States, dated August 18, 1997, regarding a ban on imports of poultry and poultry products from the EC by the U.S. Department of Agriculture's Food Safety Inspection Service and any related measures. The EC contends that although the ban is allegedly on grounds of product safety, the ban does not indicate the grounds upon which EC poultry products have suddenly become ineligible for entry into the U.S. market. We coded this as noncontinuous.

${ }^{25}$ For example, a complaint by Canada against the EC (WT/DS135), dated May 28, 1998, involves measures by France that bar asbestos and products containing asbestos on the basis of health and safety concerns. We code this and all cases involving health and safety measures as noncontinuous.

${ }^{26}$ For example, cases WT/DS62, 67, and 68 involve a complaint by the United States about the EC's reclassification for tariff purposes of certain local area network (LAN) adapter equipment and personal computers with multimedia capability. We coded this and all classification complaints as noncontinuous.

${ }^{27}$ For example, case WT/DS176/1, dated July 8, 1999, involves a complaint by the EC that Section 211 of the U.S. Omnibus Appropriations Act effectively makes impermissible the registration or renewal in the United States of a trademark if it was previously abandoned by a trademark owner whose business and assets have been confiscated under Cuban law. Another example would include a complaint by the United States against Mexico (WT/DS204/1), dated August 29, 2000, which alleged that the Mexican government failed to take needed regulatory action in Mexico's basic and value-added telecommunications sectors, in violation of obligations under the General Agreement on Trade in Services with respect to basic and valueadded telecommunications services. We code both of these cases as noncontinuous.
} 
TABLE 3

Developmental Combinations of Complainants and Defendants

\begin{tabular}{|c|c|c|c|c|c|c|c|}
\hline & 1995 & 1996 & 1997 & 1998 & 1999 & 2000 & Total \\
\hline Developed versus developed & $14(56)$ & $17(35)$ & $27(55)$ & $25(59)$ & $21(60)$ & $9(32)$ & $112(49)$ \\
\hline Developed versus developing & $1(4)$ & $14(29)$ & $14(29)$ & $12(29)$ & $7(20)$ & $8(29)$ & $56(25)$ \\
\hline Developing versus developed & $8(32)$ & $14(29)$ & 7 (14) & $4(10)$ & $4(11)$ & $3(11)$ & $40(18)$ \\
\hline Developing versus developing & $2(8)$ & $3(6)$ & $1(2)$ & $1(2)$ & $3(9)$ & $8(29)$ & $18(8)$ \\
\hline Total & $25(100)$ & $48(100)$ & $49(100)$ & $42(100)$ & $35(100)$ & $28(100)$ & $227(100)$ \\
\hline
\end{tabular}

NoTE. - Complainants are listed first in each pair. Numbers in parentheses are percentages.

early resolutions, as the smaller economy gives in more readily to the demands of the more powerful. Complainants with a good deal of economic leverage over the defendant might be especially able to extract and employ implicit threats of retaliation in order to avoid a panel. On the other hand, fairly symmetrical disputing pairs might be more likely to resort to panels if neither side has the leverage to force a concession from the other.

We include a number of indicators that attempt to capture the relative power of the disputing parties. The first of these is a set of four simple dummy variables to indicate whether the disputing pair involves a developed complainant versus a developed defendant, a developed complainant versus a developing defendant, a developing complainant versus a developed defendant, or a developing complainant versus a developing defendant. (We define "developed" here as a member of the Organization for Economic Cooperation and Development, the OECD.) Table 3 displays the various combinations of disputants since the inception of the WTO dispute settlement process. About half of our cases involve OECD countries suing one another. About a quarter of the cases involve OECD countries suing developing members of the WTO. There appears to be a significant decline over time in the incidence of developing countries suing their wealthier counterparts. The smallest proportion involves complaints among non-OECD countries, though the number of cases in this category nearly equals that of OECD versus OECD cases for the year 2000. If the logic of asymmetrical power relations encourages settlement through negotiations, we would expect the first and fourth combinations to be associated with escalation to panels.

These dichotomous combinations are very crude measures of relative power; specifically, tremendous variation in relative market power between disputants can obtain across cases lumped under a single combination. We therefore also include a continuous measure of economic power: a country's gross domestic product (GDP). In one specification, we consider only the GDP of the complainant, ${ }^{28}$ on the assumption that a large complainant can

\footnotetext{
GDP.

${ }^{28}$ We perform tests using both raw GDP data as well as the natural log of the complainant's
} 
get concessions far more easily than a smaller one. In a separate specification, we more explicitly recognize that market power is inherently relational and use the difference in GDP between the two disputing parties. In this case, we take the log of the absolute value of the difference in GDP. The greater this number, the more swiftly the smaller country should make concessions during consultations, and the less likely the case should be to escalate to the panel phase.

Finally, we propose a measure of economic power that more explicitly taps into specific bilateral trading relationships. The WTO is largely in the business of settling struggles over the terms of access to a domestic market. A high degree of dependence on such access is likely to reduce the bargaining power of the complainant, since it is more likely to make concessions in order not to jeopardize the access it currently enjoys. The greater the dependence of the complainant on the export market of the defendant, the more willing the complainant should be to accept concessions, and the less likely it is that the case will escalate. ${ }^{29}$ As above, we also attempt specifications in which we look at the asymmetry of such export dependence: the greater the difference between the complainant's dependence on the defendant (relative to the complainant's GDP) and the defendant's export dependence on the complainant (relative to the defendant's GDP) ${ }^{30}$ the more likely the more export dependent party is to make acceptable concessions in consultations, and the less likely the need for a panel.

National institutional factors might also affect countries' ability to settle in the consultation phase. We think of these factors in terms of constraints that make it difficult to make concessions, as well as factors that are alleged to reflect a preference for transparent, quasi-judicial procedures for settlement. Two kinds of constraints-the nature of the governmental system and the regime type-may have important implications for the ability to settle in consultations. Whether a government is parliamentary or presidential can have a significant impact on the ability of the negotiator (usually part of the executive branch of government) to offer concessions in a trade dispute. Parliamentary governments do not face the same degree of independent legislative input into trade policy that presidential governments potentially do. In presidential systems, on the other hand, the executive may wish to concede for the sake of settlement but face a far more protectionist domestic legislature that has the ultimate authority to veto such concessions. A binding panel decision is an attractive solution for such governments. Judith Goldstein, for example, has shown how the binational panels that settle disputes arising

\footnotetext{
${ }^{29}$ The precise indicator we use is the total value of the complainant's exports to the defendant as a proportion of the complainant's GDP.

${ }^{30}$ Absolute value of (Exports of C to D/C's GDP) - (Export's of D to C/D's GDP), where $\mathrm{C}$ is the complainant and $\mathrm{D}$ is the defendant.

Absolute value of (exports $\left.\mathrm{C} / \mathrm{GDP}_{\mathrm{C}}\right)-\left(\right.$ exports $\left._{\mathrm{D}} / \mathrm{GDP}_{\mathrm{D}}\right)$, where $\mathrm{C}$ is the complainant and $\mathrm{D}$ is the defendant.
} 
from the Canada-U.S. Free Trade Agreement tend to favor the freer trade orientation of the U.S. executive compared to the relatively more protectionist Congress. ${ }^{31}$ Parliamentary systems certainly do not involve the same dynamics of potential legislative obstruction. Concessions should be easier in the absence of such a constraint. Executives under presidential systems, however, may have incentives to delegate up to an authoritative third party for a binding ruling rather than risk making a political concession that the legislature might oppose or obstruct.

The distinction between parliamentary/presidential systems is well recognized in comparative politics, and a number of well-used data sets contain indicators that distinguish the two. We have chosen to use two sources: the World Bank and Freedom House, a nongovernmental organization that records and publicizes political conditions it believes are relevant to individual "freedom." There is a very high degree of correspondence between these two sources. The problem arises, however, of how to code the EC, which neither of these sources attempts to do. Since we are trying to tap into the degree of constraint on the negotiators, we have decided to rate the EC as "presidential." While the EC Commission monopolizes the representation of the EC in negotiations, it is subject to fairly close control by the Council of Ministers. It is bound by detailed guidelines formulated by the council ("bargaining mandate") and has to report progress and problems in the negotiations to the Article 133 Committee, a special committee of the council. Trade agreements are made by the council on recommendation of the commission. ${ }^{32}$ The constraints on the commission by the member states seem far greater than those that a parliament would place on its governmental negotiator. A "presidential" rating seems appropriate for the EC.

The decision to escalate to panels might also be affected by the degree of democracy of the disputants. First, highly democratic polities potentially involve a high degree of input from interest groups with a stake in the outcome of the dispute. Much of the literature on the political economy of trade shows that producers are much more likely to be organized to protect their interests than are consumers. ${ }^{33}$ Highly democratic societies are likely to be besieged by import-competing producers when they are defendants and exporters when they are claimants, and these demands ratchet up the political costs associated with making concessions in consultations. For these reasons, one would expect democracies to face larger transaction costs generated by interest group demands. In that case, democracies may be more willing to "delegate up"

\footnotetext{
${ }^{31}$ Judith Goldstein, International Law and Domestic Institutions: Reconciling North American "Unfair" Trade Laws, 50 Int'l Org. 541 (1996).

${ }^{32}$ The decision to code the EC as presidential follows from helpful communications on this issue with Tanja Boezel and Ernst-Ulrich Petersman.

${ }^{33}$ See the discussion in Michael Gilligan, Empowering Exporters: Reciprocity, Delegation, and Collective Action in American Trade Policy (1997).
} 
to a WTO panel to resolve the trade dispute-and disperse the political heat the government would have to endure for making a concession.

Marc Busch offers an additional reason to expect that democracies will find it hard to settle and will tend to invoke the assistance of panels. Drawing from the international relations literature that deals with interstate disputes, ${ }^{34}$ he argues that democracies have a greater commitment to legal forms of dispute settlement than do nondemocracies. "To the extent that panels are formal, transparent, and guided by case law," Busch writes, "they would appear to give democracies much of what they value in domestic institutions, and thus are more likely to be used where pairs of democracies can 'externalize' these processes of dispute resolution., ${ }^{35}$ Essentially, this is an affinity argument: democracies prefer and trust international adjudicatory processes because they resonate with domestic institutions and processes. Busch finds that, under GATT procedures, highly democratic pairs are more likely to use panels than to settle in consultations. We suggest a specification in which the argument about democratic constraints seems more plausible than the affinity argument advanced by Busch.

Data on the degree of democratic governance is easily available and well accepted in the political science literature. The standard source is the POLITY III data set. ${ }^{36}$ This measure of democracy attempts to capture the extent to which a polity is characterized by broad participation in a competitive political process. Scores range from 0 (nondemocratic) to 10 (highly democratic). Once again, we run into difficulties over how to rate the European Community. Certainly, this is an institution that is ultimately responsible to democratically elected governments. However, popular input into European institutions themselves is limited to the European Parliament, which has a very limited role in policy formation. We decided, therefore, to rate the EC highly (9), but not as highly as the individual democracies of which it is composed.

Countries involved in disputes before the WTO tend to be very democratic. Table 4 shows that 80 percent of the complainants and 71 percent of the defendants score 9 or above on the POLITY democracy scale. The preponderance of democratic governments means that many of these disputes involve highly democratic pairs. If we define "highly democratic" as a score above 7 , then the number of cases involving democratic pairs in our data set totals 169 , or 74 percent of the total cases brought to the WTO to date. Appendix B provides the POLITY scores for every disputing country in our data set.

${ }^{34}$ William Dixon, Democracy and the Peaceful Settlement of International Conflict, $88 \mathrm{Am}$. Pol. Sci. Rev. 14 (1994); Gregory Raymond, Democracies, Disputes, and Third-Party Intermediaries, 38 J. Conflict Resol. 24 (1994).

${ }^{35}$ Busch, supra note 19.

${ }^{36}$ For a description of the POLITY III data set, see Keith Jaggers \& Ted Robert Gurr, Tracking Democracy's Third Wave with the POLITY III Data, 32 J. Peace Res. 469 (1995). 
TABLE 4

Degree of Democracy of Complainants and Defendants

\begin{tabular}{lcc}
\hline \hline Democracy Score & Complainant & Defendant \\
\hline 0 & $2(1)$ & $3(1)$ \\
1 & 0 & $3(1)$ \\
2 & $1(.5)$ & 0 \\
3 & $1(.5)$ & $1(.5)$ \\
4 & $5(2)$ & $2(1)$ \\
5 & 0 & 0 \\
6 & $6(3)$ & $5(2)$ \\
7 & $10(4)$ & $22(10)$ \\
8 & $21(9)$ & $31(14)$ \\
9 & $73(32)$ & $58(26)$ \\
10 & $108(48)$ & $102(45)$ \\
\hline
\end{tabular}

SoURCE. - Polity III data set.

Note. - Scores of 10 are highly democratic; scores of zero are nondemocratic. Total $N=227$. Numbers in parentheses are percentages.

Finally, we control for the general degree of trade dependence of the parties to the dispute. One obvious hypothesis is that countries that are highly trade dependent want clear rules regarding rights of access to foreign markets. Such rules should reduce the transaction costs of negotiating future access to the extent that they provide guidelines for how to think about classes of like complaints. Clear expectations about how to interpret treaty law may discourage questionable practices, an outcome in which the most highly trade dependent countries generally have an interest. We therefore include a measure of jointly high trade dependence for the disputants. ${ }^{37}$ Our expectation is that trade dependence increases the demand for a clear ruling, which encourages the parties to appeal to panels for a resolution.

Some other issues that may be relevant to settlement were not tested, primarily owing to a lack of data. For example, it may be the case that highprofile cases such as the Beef Hormones case ${ }^{38}$ or the Bananas dispute ${ }^{39}$ are more difficult to settle because of their political saliency. Unfortunately, we were unable to identify a sensible method of measuring this sort of political salience across countries. Measures such as the number of times a dispute is mentioned in the popular press are not only exceedingly difficult to find outside the United States and perhaps a few other states, they are also biased in favor of countries with many news publications and with publications that

\footnotetext{
${ }^{37}$ Joint trade dependence is measured as the natural log of the product of both countries' ratio of imports plus exports to GDP: $\log \left(\left[\right.\right.$ imports $_{\mathrm{C}}+$ exports $\left.\left._{\mathrm{C}}\right] / \mathrm{GDP}_{\mathrm{C}}\right)\left(\left[\right.\right.$ imports $_{\mathrm{D}}+$ exports $\left._{\mathrm{D}}\right] /$ GDP $_{\mathrm{D}}$ ).

${ }^{38}$ See EC Measures Concerning Meat and Meat Products, WT/DS48/R/CAN, WT/DS48/R/ US (panel reports); WT/DS26/AB/R, WT/DS48/AB/R (appellate panel reports).

${ }^{39}$ See European Communities-Regime for the Importation, Sale and Distribution of Bananas, WT/DS27/R; Michelle Williams, Caribbean Shiprider Agreements: Sunk by Banana Trade War? 31 U. Miami Inter-Am. L. Rev. 163 (2000).
} 
tend to be longer. ${ }^{40}$ Similarly, if one subscribes to the theory that the parties are prone to optimism, one might expect that complex or high-stakes cases would be harder to settle. Measuring either the size of the stakes or the complexity, however, is difficult, especially with respect to settled cases where there is very little evidence of the costs involved or the political importance of a dispute.

\section{Analysis and Results}

How persuasive is the argument that transaction costs associated with the nature of the dispute-its continuous versus "lumpy" character-contribute to the use of panels for settlement? To answer this question, we use a logit specification, in which the dependent variable takes on a value of 1 if a panel was formed to resolve the dispute and 0 otherwise (see Appendix $\mathrm{C}$ for the list of variables). Logit is appropriate in cases such as this in which the dependent variable is dichotomous. Table 5 presents the results. The various explanations for the propensity to proceed to a panel are listed in the Explanatory Variables column of the table. Several different models are presented in succeeding columns, in order to give a sense of the robustness of the findings. We present the logit coefficients and robust standard errors in parentheses below each.

The results do suggest that transaction costs are very likely to explain the use of panels to settle disputes that have been reported to the WTO. However, the effects may not be as straightforward as our theory anticipated. The nature of the issue under dispute-its lumpy versus continuous nature-noticeably increases escalation to panels for democratic countries. In other words, the effect of "lumpiness" is highly conditional on the nature of the political system of the negotiators. This is captured in the interaction term (Lumpy and Democratic Pair), which appears in all five models. Since both of these variables are dichotomous $(0,1)$, their interpretation is straightforward. For nondemocratic pairs, lumpiness does not increase the propensity to form panels (in fact, the negative coefficient on Lumpy indicates that, if anything, the effect might be negative, although this effect is not statistically significant in the first two models). A very different story emerges with respect to pairs of democratic countries. When democratic pairs negotiate lumpy issues, they are statistically much more likely to bump the dispute up from the consultation phase by forming panels. This result is seen by summing the coefficients on Democratic Pair $(-1.19)$ and Lumpy and Democratic Pair (1.88) for a total positive coefficient of .69 (according to model 1 , for example). The conditional standard error for the effect of a democratic pair of disputants given a lumpy issue indicates greater than 95 percent confidence

\footnotetext{
${ }^{40}$ The New York Times or Wall Street Journal, for example, has many more pages than Le Monde. Measuring salience on the basis of newspaper stories, then, would give undue weight to cases salient in the United States relative to France.
} 
TABLE 5

Logit Coefficients for the Propensity to Proceed to a Panel

\begin{tabular}{|c|c|c|c|c|c|}
\hline Explanatory Variables & (1) & (2) & (3) & (4) & (5) \\
\hline Constant & $\begin{array}{c}-1,065^{* *} \\
(339)\end{array}$ & $\begin{array}{c}-1,196 * * \\
(356)\end{array}$ & $\begin{array}{c}-1,120^{* *} \\
(353)\end{array}$ & $\begin{array}{c}-1,131^{* *} \\
(358.7)\end{array}$ & $\begin{array}{c}-1,094 * * \\
(358)\end{array}$ \\
\hline Year & $\begin{array}{l}.534 * * \\
(.170)\end{array}$ & $\begin{array}{l}.601^{* *} \\
(.178)\end{array}$ & $\begin{array}{l}.563^{* * *} \\
(.177)\end{array}$ & $\begin{array}{l}.569 * * \\
(.180)\end{array}$ & $\begin{array}{l}.550^{* *} \\
(.180)\end{array}$ \\
\hline Lumpy & $\begin{array}{r}-1.028 \\
(.722)\end{array}$ & $\begin{array}{r}-1.24 \\
(.762)\end{array}$ & $\begin{array}{l}-1.34^{+} \\
(.779)\end{array}$ & $\begin{array}{r}-1.34^{+} \\
(.778)\end{array}$ & $\begin{array}{r}-1.33^{+} \\
(.781)\end{array}$ \\
\hline Democratic Pair & $\begin{aligned}-1.19 * \\
(.545)\end{aligned}$ & $\begin{aligned}-1.47^{*} \\
(.623)\end{aligned}$ & $\begin{aligned}-1.33 * \\
(.631)\end{aligned}$ & $\begin{array}{r}-1.23^{+} \\
(.647)\end{array}$ & $\begin{array}{r}-1.20^{+} \\
(.648)\end{array}$ \\
\hline Lumpy and Democratic Pair & $\begin{array}{l}1.88^{*} \\
(.828)\end{array}$ & $\begin{array}{l}2.03^{*} \\
(.882)\end{array}$ & $\begin{array}{l}1.95 * \\
(.876)\end{array}$ & $\begin{array}{l}1.86^{*} \\
(.897)\end{array}$ & $\begin{array}{l}1.83 * \\
(.892)\end{array}$ \\
\hline $\begin{array}{l}\text { Complainant's Exports to } \\
\text { Defendant }\left(\times 10^{-7}\right)\end{array}$ & $\begin{array}{c}-9.94 \\
(6.73)\end{array}$ & $\begin{aligned}-10.9 \\
(6.89)\end{aligned}$ & $\begin{array}{r}-20.1^{+} \\
(10.8)\end{array}$ & $\begin{array}{r}-18.6^{+} \\
(10.0)\end{array}$ & $\begin{array}{r}-15.4^{*} \\
(7.65)\end{array}$ \\
\hline Log GDP of Complainant & $\begin{array}{c}-.058 \\
(.100)\end{array}$ & $\begin{array}{c}-.127 \\
(.102)\end{array}$ & $\begin{array}{r}-.187^{+} \\
(.111)\end{array}$ & $\begin{array}{r}-.201^{+} \\
(.112)\end{array}$ & $\begin{array}{r}-.193^{+} \\
(.111)\end{array}$ \\
\hline LDC v. LDC & & $\begin{array}{c}-2.70^{+} \\
(1.48)\end{array}$ & $\begin{array}{l}-2.45 \\
(1.52)\end{array}$ & $\begin{array}{l}-2.55^{+} \\
(1.55)\end{array}$ & $\begin{array}{c}-2.19 \\
(1.61)\end{array}$ \\
\hline Trade-Dependent Pair & & & $\begin{array}{l}.131^{+} \\
(.070)\end{array}$ & $\begin{array}{l}.106 \\
(.073)\end{array}$ & $\begin{array}{l}.106 \\
(.072)\end{array}$ \\
\hline Parliamentary Pair & & & & $\begin{array}{c}-.631 \\
(.771)\end{array}$ & \\
\hline Log GDP Difference & & & & & $\begin{array}{l}.134 \\
(.119)\end{array}$ \\
\hline Number of observations & 151 & 150 & 150 & 150 & 150 \\
\hline Wald $x^{2}$ & 18.16 & 16.13 & 18.47 & 18.74 & 20.35 \\
\hline$P>x^{2}$ & .006 & .024 & .020 & .028 & .016 \\
\hline
\end{tabular}

NoTE. - Robust standard errors are in parentheses. Variables are explained in Appendix C.

$+P>Z=.10$.

$* P>Z=.05$.

** $P>Z=.01$.

in this conclusion..$^{41}$ When democracies negotiate continuous issues, such as a tariff or quota, our results suggest they are significantly less likely than nondemocratic pairs to go to panels. The negative and statistically significant coefficient on Democratic Pair in all specifications of the model increases our confidence that democracies can settle without a panel-as long as the issue over which they are disputing can be relatively easily divided. Contrary to empirical work on the GATT (pre-1995), which suggests that democracies are likely to escalate ${ }^{42}$ we find this to be the case for disputes submitted to the WTO only when political compromise is inherently difficult. The difficulties the United States, Canada, and Europe have had conceding on health and safety issues from asbestos to beef hormones provide an empirical referent for this finding.

It is important to stress how these results differ from our original expec-

${ }^{41}$ The conditional standard errors do not quite reach levels of statistical significance in models $3-5$, but this may be due to the inclusion of irrelevant variables that perturb otherwise stable results.

${ }^{42}$ Busch, supra note 19. 
tations. Contrary to our assumption that there would be a simple positive relationship between the discontinuous nature of the issue area and the tendency to escalate to panels, this factor is highly conditioned on the nature of the regimes involved in negotiations. Why should this be the case? One possibility is that democratic regimes find it much harder to make political concessions with respect to discontinuous issues because they find it much harder to fashion a set of side payments that would satisfy a trade partner without stimulating domestic political opposition. In effect, the set of possible bargains may be much smaller because of the possibility of politically costly opposition from groups who bear the costs of such side payments ${ }^{43}$ Nondemocratic regimes are not likely to be as sensitive to the costs that side payments for settlement involve. They are more likely to control a larger set of resources that they can tap without political approval, thus improving their ability to provide a side payment in return for concessions. We suggest this may explain the important conditional nature of the issue-regime interaction. ${ }^{44}$

Several of the control variables were statistically significant as well and bear some discussion. There is some evidence to suggest that as the complainant's exports to the defendant increase, there is a greater tendency to settle in the consultation phase, as we expected. Large complainants appear generally to increase the probability of settlement, though this relationship is not statistically significant across all models. The difference in size between complainant and defendant did not contribute much to our explanation, as the insignificant coefficient on Log GDP Difference suggests.

Hoping to find some effect to the relative power of the two parties, we also ran these models with every combination of developing/developed complainants/defendants. Only the combination of one developing country versus

${ }^{43}$ This is consistent with informational theories of international crisis behavior that are regime contingent. Kenneth Schultz, for example, argues that owing to greater transparency, democratic governments are able to send especially credible signals, from which by their very nature it is difficult to back down. See Kenneth A. Schultz, Do Democratic Institutions Constrain or Inform? Contrasting Two Institutional Perspectives on Democracy and War, 53 Int'l Org. 233 (1999). The result in our context is that democratic governments find it especially difficult to negotiate away a discontinuous good once they have made a public commitment to provide and defend it against external demands.

${ }^{44}$ This effect is somewhat attenuated by our decision to treat all cases dyadically. When we entered a dummy variable for each dyadic pair that was part of a multiple-complainant case, we found the same substantive effects, except that lumpy issues for nondemocracies were even more likely to be associated with settlement. This could be because cases in which multiple complainants are involved are also somewhat likely to be lumpy (correlation of .31). For example, two important cases, Shrimp Turtle (WT/DS58, involving complaints against the United States by India, Malaysia, Pakistan, and Thailand) and the Bananas case (WT/DS27, involving the United States, Ecuador, Guatemala, Honduras, and Mexico), were coded as lumpy and involved multiple complainants. It would be desirable to examine whether multiple complainants also make it hard to make concessions in relatively discontinuous issue areas. However, we were unable to calculate a standard error for a specification in which the effects of the lumpy issue area is conditioned on multiple complainants because the number of cases was too small. 
another was statistically significant. Interestingly, when developing countries have a trade dispute with one another, they are less likely to escalate to panels than is the case with all other combinations. A number of explanations for this result are possible. An obvious candidate is the relative lack of resources to pursue cases in a legalistic setting..$^{45}$ Another reason might be more closely related to the transaction cost story we are developing here: because these countries are less likely to trade intensively with one another, they have less incentive to develop general rules that would govern their future trading relationships. An ad hoc compromise would seem to suffice among developing countries, given the more significant problem of access to the markets of the OECD and the relative thinness of their mutual trade.

A mutually high degree of trade dependence is likely to contribute to the formation of panels, as we expected on the basis of the desire to establish clear rules that reduce transaction costs. While only barely statistically significant in one specification, this relationship is what we would have expected from country pairs for whom a significant share of their GDP is traded. These countries have an especially strong incentive to reduce transaction costs and to make the rules of international trade transparent and consistent.

\section{Future Research and Possible Extensions}

This article has advanced a theory of settlement and litigation within the WTO in which the key variable is the "lumpiness" of the dispute's subject matter. Additional theories of settlement exist, and we do not claim to have tested them fully. For example, in some cases, settlement may be frustrated by informational asymmetries or asymmetries in the payoffs received by political leaders in the event of settlement. Further investigation of these issues would be useful.

Even within the context of out theory of settlement, this paper, like all empirical studies, could have considered additional control variables. We have tried to incorporate as many plausible controls as possible, but some potentially relevant ones are unavailable and have poor proxies. For example, one might think that the value of a dispute would impact the likelihood of settlement. The empirical difficulty here is that the value of a dispute includes a variety of issues that are impossible to measure. The most obvious of these variables are the economic injury suffered by the complainant and the economic impact of the action on the defendant. Even these measures are difficult to obtain, of course, because we do not have direct information about how the actions affected trade flows and revenues. Making the problem more difficult is the fact that decision makers may be concerned with something

\footnotetext{
${ }^{45}$ We assume zero litigation costs in our model, although this is likely to be inappropriate for the poorer members of the WTO. See Edward Kwakwa, Regulating the International Economy: What Role for the State? in International Law and International Politics 233 (Michael Byers ed. 2000).
} 
other than simply the economic impact of the dispute. Rather, they are likely to care about its impact on their own welfare. There is, therefore, a political calculus that would be required to identify the value of the dispute to the leaders.

A second variable that might be relevant is the prominence of the dispute. Most trade disputes proceed without significant public attention, though a minority become national news. This is true in the United States, but even more so in smaller states where trade plays a larger role. One might imagine a proxy for prominence that consists of a count of related newspaper stories, for example, but as previously discussed, this and other possible proxies have serious problems and biases. ${ }^{46}$

Finally, like so much else in the international arena, settlement at the WTO is affected by domestic politics. In a perfect world, one would account for these domestic influences. In our imperfect world, however, there is no way to account for the complex domestic political influences on trade negotiations. Even in a case study, it is often difficult to identify causal relationships between domestic politics and international behavior. In a study of the sort presented here, it is simply not possible to control for all domestic issues. We try to control for as many of these as possible by controlling for a state's type of government (presidential or parliamentary), the state's level of democracy, and a variety of trade measures.

\section{CONCLUSION}

Very little empirical work exists on the political economy of dispute settlement in the context of the WTO. Even less exists that attempts to tie empirical results to a reasonably coherent theoretical framework. One way to do this is to appeal to theories of transaction costs in order to understand just why sovereign governments engaged in a dispute are sometimes unable to reach a negotiated settlement and instead opt for a panel.

Two streams of research have profitably used the insights of transaction costs economics to address questions of this kind. The law and economics literature has long analyzed issues of "settling out of court" as amenable to this class of models. From another disciplinary perspective, certain strands of the international relations literature since the 1980s have understood the creation of international institutions as a way to reduce the growing transaction costs associated with increased interdependence between sovereign states. ${ }^{47}$ These approaches have informed our thinking about issues of delegation to the Dispute Settlement Mechanism of the WTO.

The major findings of this paper center on the nature of the disputed issue

${ }^{46}$ See text around note 40 supra.

${ }^{47}$ Robert O. Keohane, After Hegemony: Cooperation and Discord in the World Political Economy (1984). 
in influencing the settlement of trade disputes. Our central hypothesis was that continuous, easily divisible problems would tend to be resolved in the consultation phase, while issues that have an all-or-nothing quality-lumpy issues-are more likely to escalate to the panel phase. Our findings suggest this is especially likely to be the case when two democracies disagree over trade. After all, highly democratic disputants are likely to face even greater domestic political consequences for making concessions than are relatively autocratic governments. Certainly, it might be possible to make an inherently lumpy issue more continuous by making side payments or attempting to engage in issue linkage. Our argument, however, is that democracies find it much harder to pull off these more complicated deals, since they are likely to affect the interests of other groups who might oppose the strategy of such linkage.

The evidence seems to suggest this is the case. When nondemocratic pairs dispute noncontinuous issues, they were no more likely (and are possibly less likely) to resort to panels. Democracies, on the other hand, were shown to resort to panels at a significantly higher rate conditional on the nature of the issue. They tend to take lumpy problems to panels. Note that our findings indicate that there is nothing inherent in democracy alone that suggests they prefer to resolve their cases before a panel. On the contrary, democratic pairs dealing with continuous issues usually settle in the consultation phase. This suggests that transaction costs, rather than legal culture or a high comfort level with "the rule of law," better account for these patterns of escalation in cases that have been submitted to the WTO's dispute settlement process. 


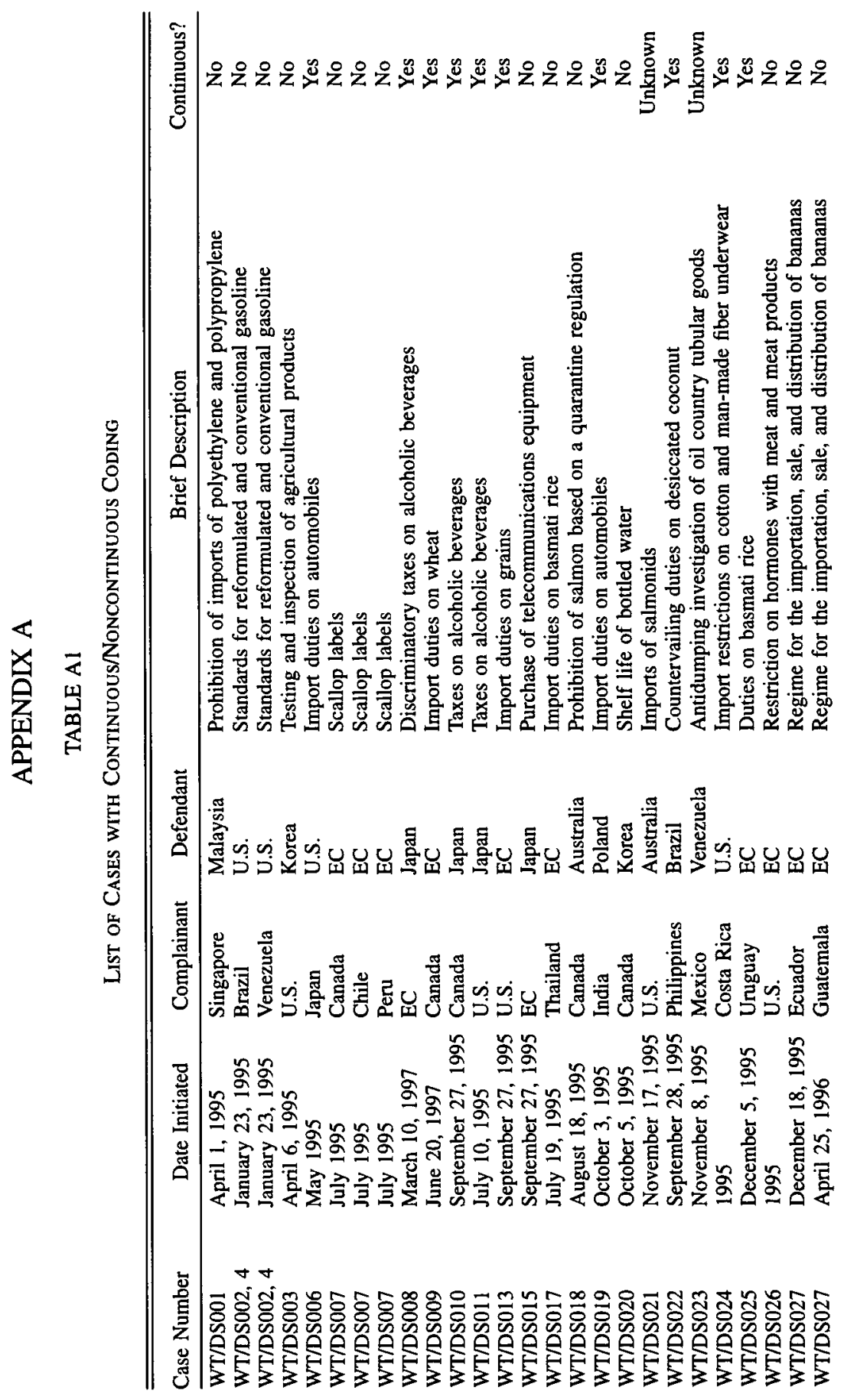




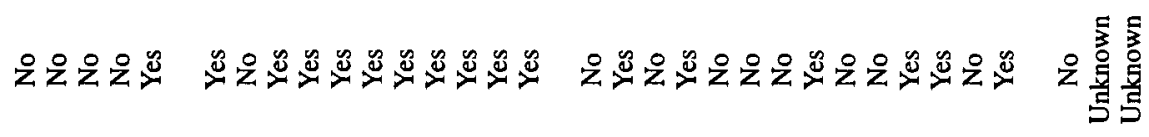

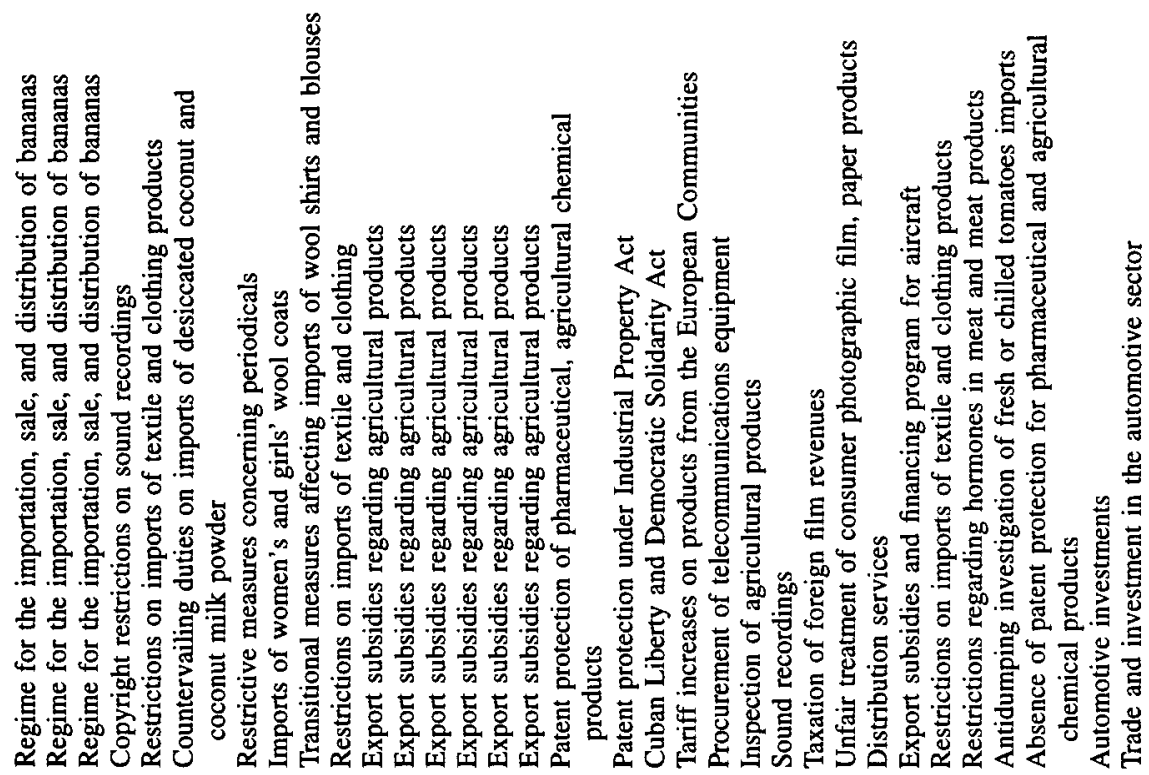

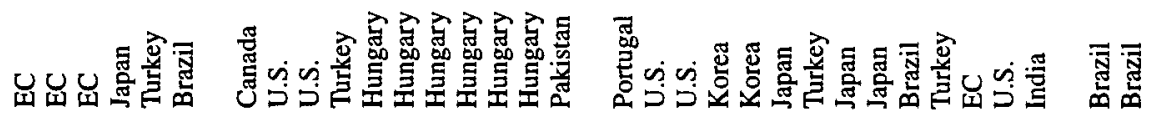

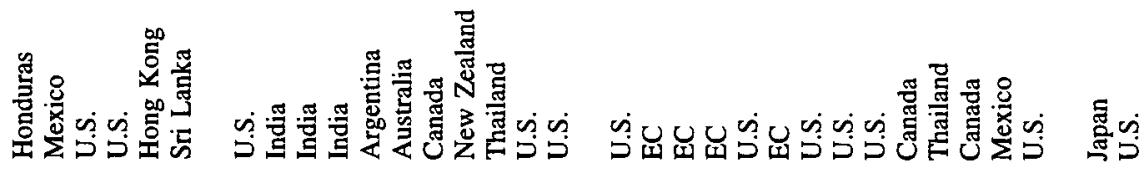

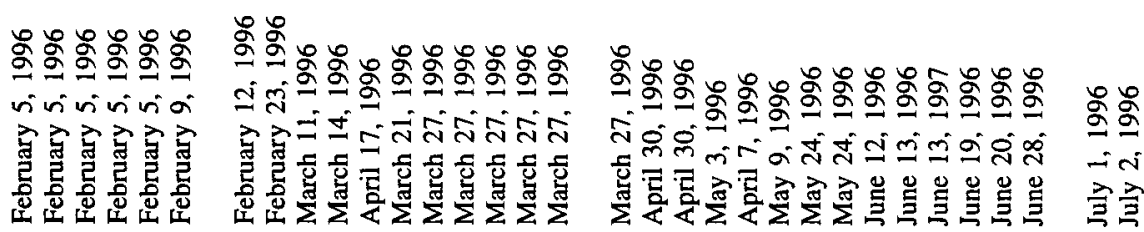

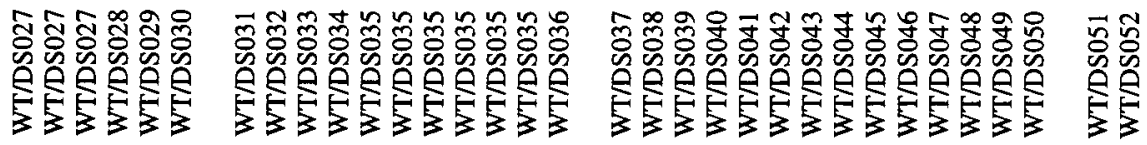




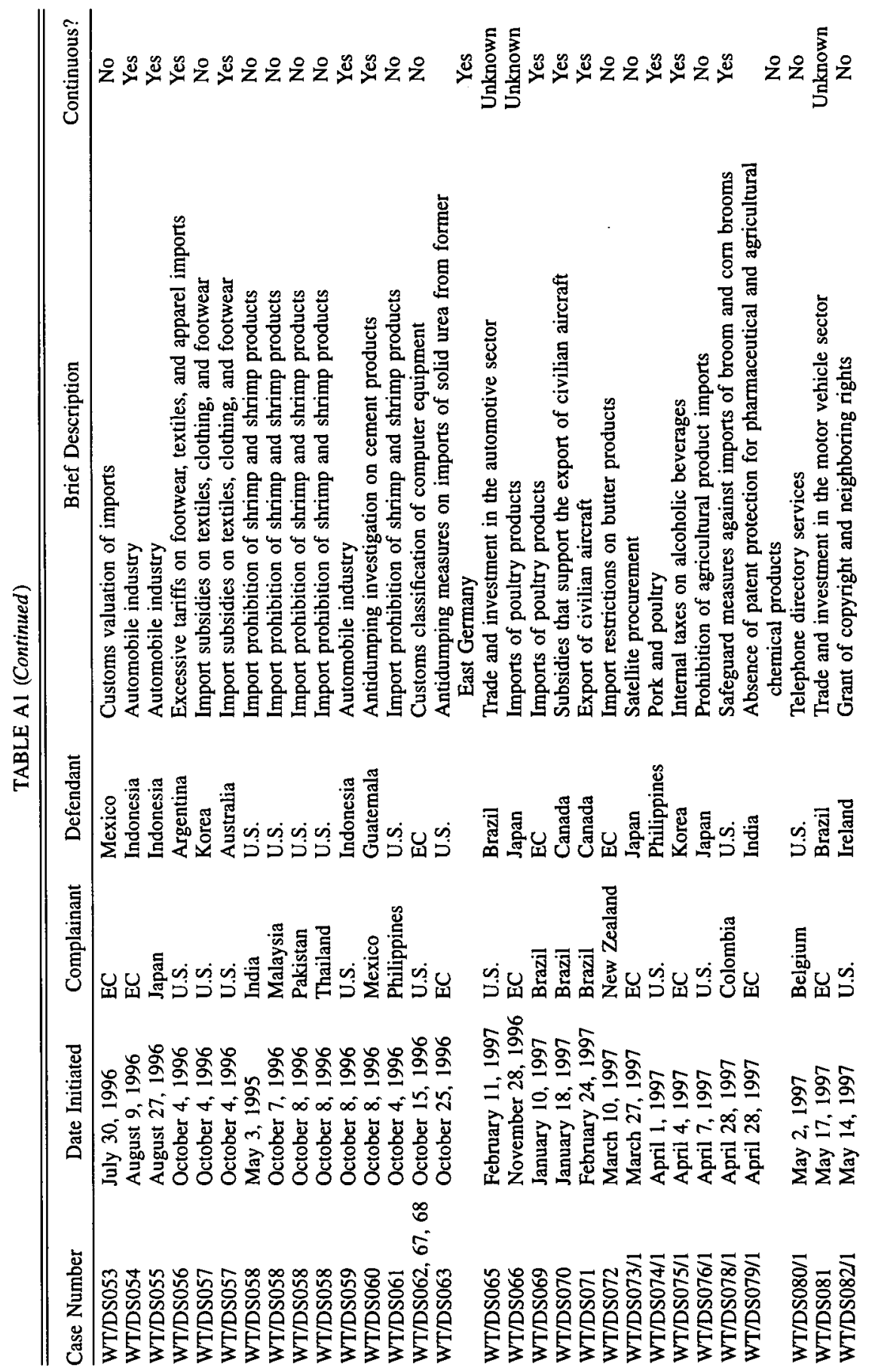




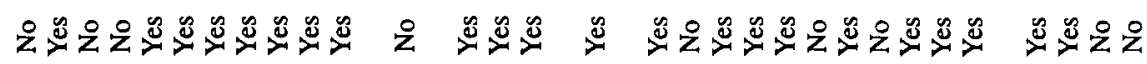

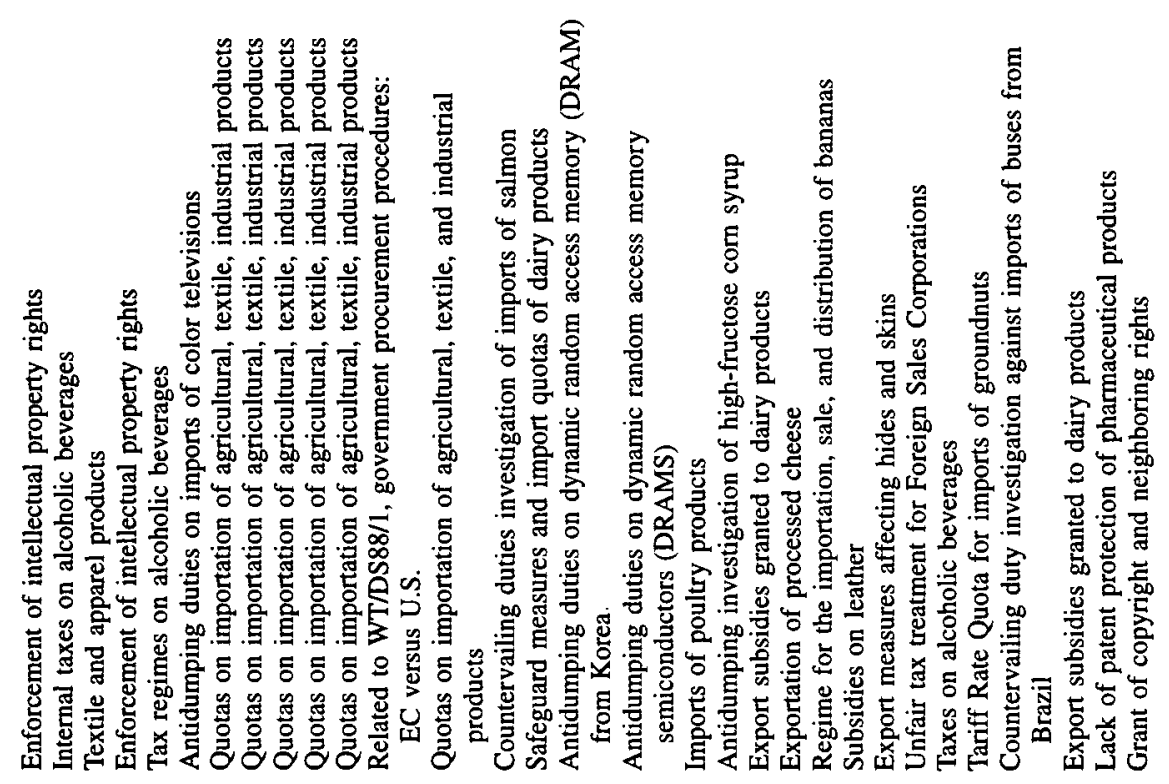

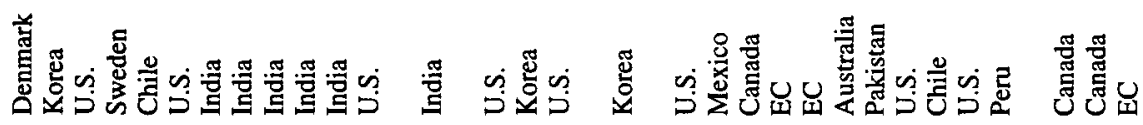

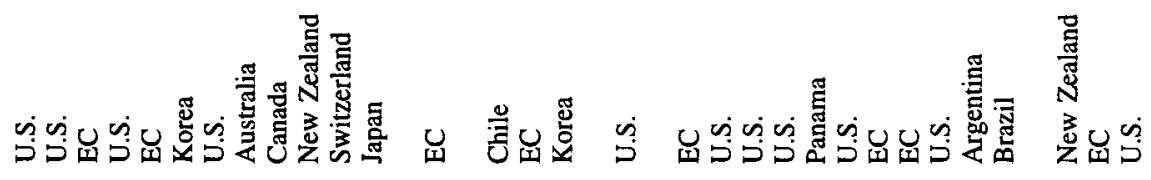

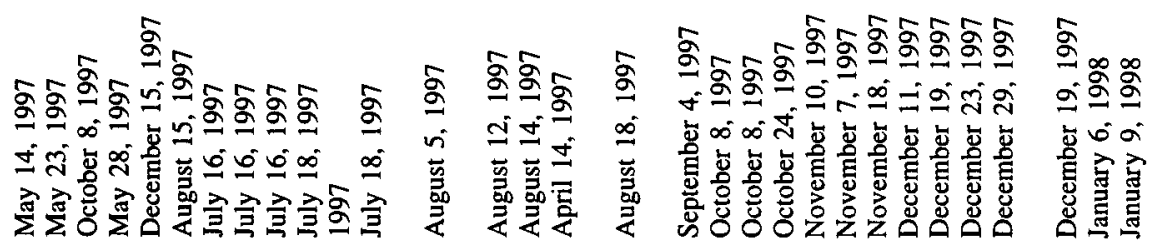

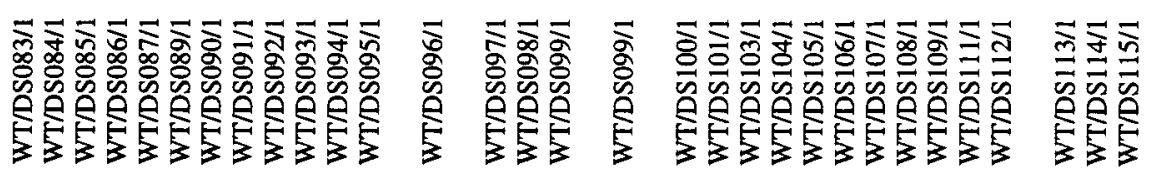




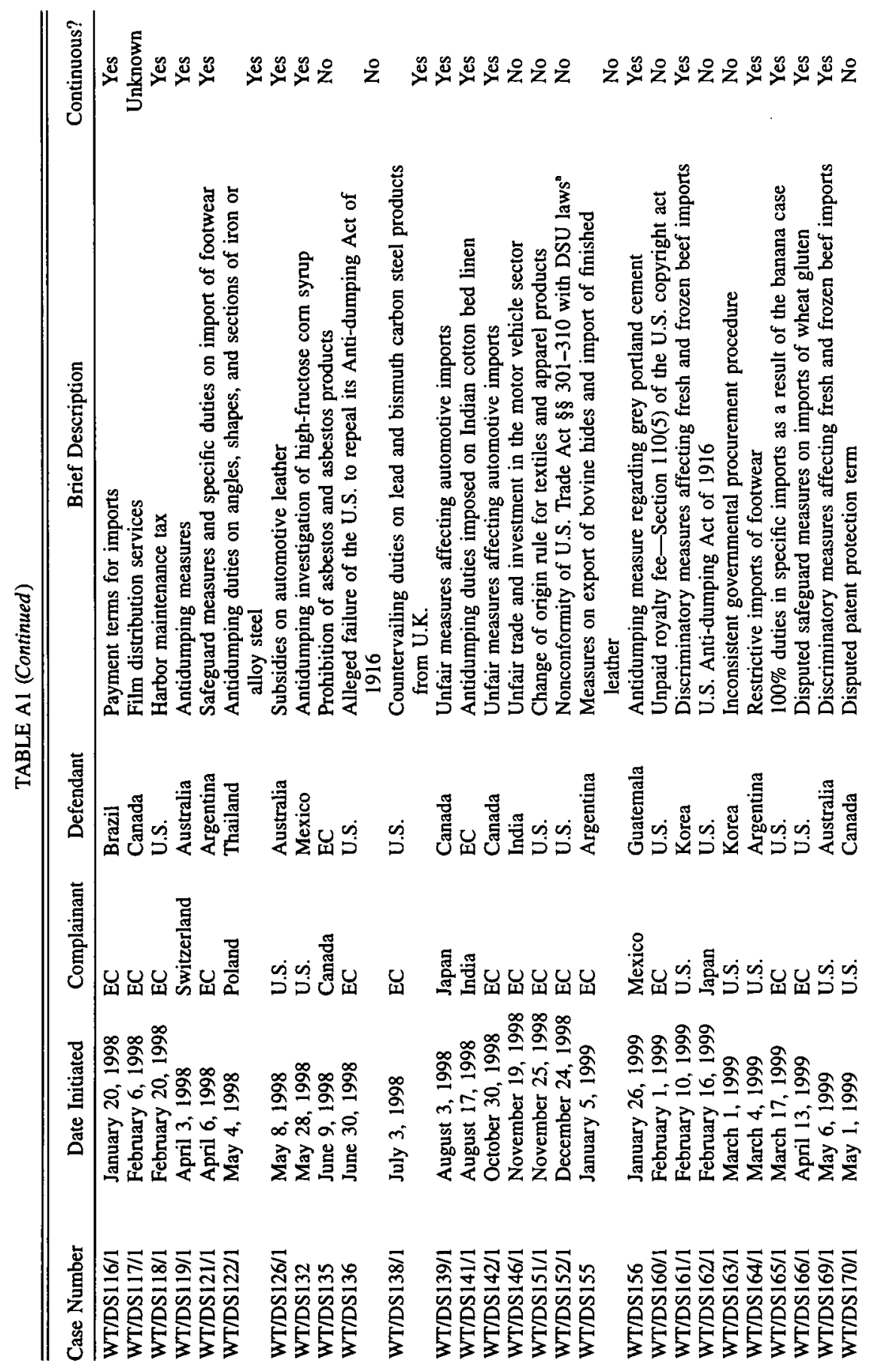




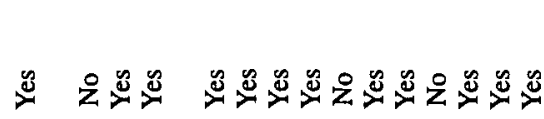

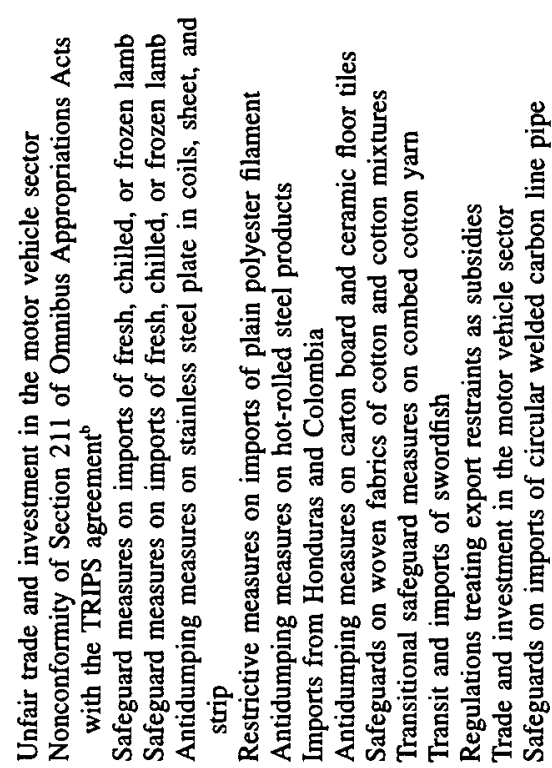

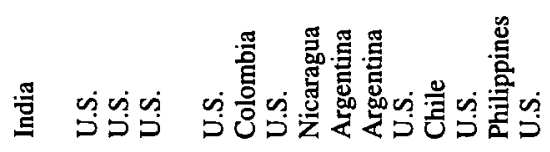

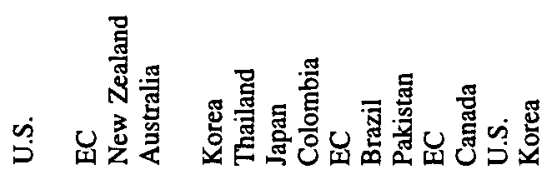

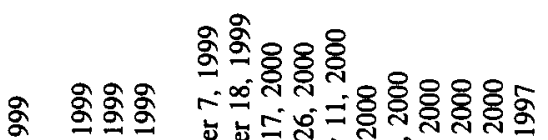

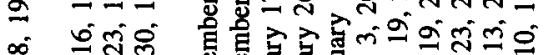

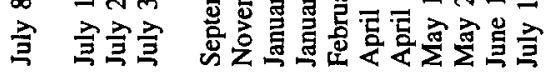

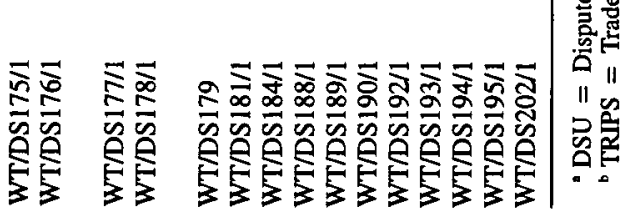




\section{APPENDIX B}

TABLE B 1

Democracy Scores for World Trade Organization Disputants

\begin{tabular}{lc|lc|lc}
\hline \hline Country & Score & Country & Score & Country & Score \\
\hline Pakistan & $0-8$ & Panama & $7-9$ & Belgium & 10 \\
Indonesia & 0 & Brazil & 8 & Canada & 10 \\
Egypt & 1 & Chile & 8 & Costa Rica & 10 \\
Romania & 1 & Hong Kong & 8 & Denmark & 10 \\
Singapore & 2 & Slovak Republic & 8 & Greece & 10 \\
Peru & 3 & Turkey & 8 & Hungary & 10 \\
Malaysia & 4 & Venezuela & 8 & Ireland & 10 \\
Mexico & $4-8$ & EC & 9 & Japan & 10 \\
Sri Lanka & 6 & France & 9 & Netherlands & 10 \\
Honduras & $6-7$ & India & 9 & New Zealand & 10 \\
Guatemala & $6-8$ & Nicaragua & 9 & Portugal & 10 \\
Ecuador & $6-9$ & Poland & 9 & Sweden & 10 \\
Korea & 7 & South Africa & 9 & Switzerland & 10 \\
Argentina & $7-8$ & Thailand & 9 & Trinidad and Tobago & 10 \\
Colombia & $7-8$ & Czech Republic & $9-10$ & United States & 10 \\
Philippines & $7-8$ & Australia & 10 & Uruguay & 10 \\
\hline
\end{tabular}

SOURCE.-POLITY III data set.

NOTE. - Scores of 10 are highly democratic; scores of 0 are nondemocratic. Ranges (for example, 7-9) indicate a change in democracy rating for different years in which the country was involved in a trade dispute. 


\section{APPENDIX C}

\section{Data Definitions and Sources \\ Dependent Variable}

Escalation to Panels. This is a dichotomous variable that takes on a value of 1 if a panel was formed to render a decision on given trade dispute and 0 otherwise (as of February 2001). Source: WTO Web site, http://www.wto.org (see cases listed under "state of play").

\section{Explanatory Variables}

Year. Year in which the case was initiated. Source: WTO Web site, http:// www.wto.org (see cases listed under "state of play").

Lumpy. A dichotomous variable that takes on a value of 1 if the dispute involves a discontinuous issue and 0 otherwise. Disputes involving outright bans, health and safety regulations, product classification issues, and the absence of required laws (such as TRIPS requirements) were coded as lumpy (1). Disputes involving tariffs, nonzero quotas, and subsidies were coded as continuous (0). Source: WTO Web site, http://www.wto.org (see cases listed under "state of play").

Democratic Pair. A dichotomous variable that takes on a value of 1 if both the complainant and the defendant are relatively democratic (scoring 8 or above on the POLITY III democracy scale) and 0 otherwise. Source: POLITY III data set. For a complete discussion of the conceptualization and coverage of this data set and comparisons with other measures of democracy, see Keith Jaggers \& Ted Robert Gurr, Tracking Democracy's Third Wave with the POLITY III Data, 32 J. Peace Res. 469 (1995).

Complainant's Exports to Defendant. The U.S. dollar value of complainant's exports to the defendant. Source: International Monetary Fund, Direction of Trade Statistics (various years).

Log GDP of Complainant. The natural $\log$ of the U.S. dollar value of the complainant's gross domestic product. Source: World Bank Web site, http:// www.worldbank.org/data/.

$L D C$ v. $L D C$. A dichotomous variable that takes on a value of 1 if both the complainant and the defendant are developing countries (defined as all countries that are not members of the OECD) and 0 otherwise.

Trade-Dependent Pair. Measured as the natural log of the product of both countries' ratio of imports plus exports to GDP: $\log$ ([importsC + exportsC]/ GDPC)([importsD + exportsD]/GDPD). Source: International Monetary Fund, Direction of Trade Statistics (various years).

Parliamentary Pair. A dichotomous variable that takes on a value of 1 if both the complainant and the defendant have parliamentary systems of government and 0 otherwise. Source: Freedom House, http://www.freedomhouse.org/research/freeworld/2000/table7.htm. Note: EC is coded as "presidential," for reasons discussed in the text.

$\log G D P$ Difference. The natural $\log$ of the absolute value of the difference in GDP of the complainant and the defendant. Source: World Bank Web site, http:// www.worldbank.org/data/. 
HeinOnline -- 31 J. Legal Stud. S236 2002 